\title{
APPLIED GEOCHEMISTRY IN SPATIAL PLANNING OF THE VRANJE REGION, (SOUTHERN) SERBIA
}

\author{
Sasa S. Rogan ${ }^{1}$ \\ Vojin B.Gordanic ${ }^{2}$ \\ Dr Milka M.Vidovic ${ }^{1}$ \\ Ivana S. Trajkovic ${ }^{1}$ \\ Milica Sentic ${ }^{1}$ \\ ${ }^{1}$ Institute of Chemistry, Technology and Metallurgy, Center of Ecology and \\ Technoeconomics/University of Belgrade, Serbia \\ ${ }^{2}$ Geo-science d.o.o., Kosovska br.18, Belgrade, Serbia
}

\begin{abstract}
In terms of development of agriculture, industry and tourism, in the spatial planning the level of exploration of mineral resources and environmental protection in rural areas is of great importance.

The area of Vranje tertiary basin, located in the western part of the Serbian-Macedonian massif was selected. It spreads on both sides of the South Morava river, from Vladicin Han at the North, via Vranje and Ristovac to Bujanovac at the South. The total length of the basin is about $30 \mathrm{~km}$ and the width varies from 10 to $17 \mathrm{~km}$.

The area located west of the Vranje basin belongs to the granodiorite massif of Bujanovac and on the east to grandiorite and quartz diorite massif of Surdulica, in which the wolfram ore, occurrences and deposits of lead zinc, copper, iron, phosphorites and in the basin radioactive anomalies are registered.

Geological and structural characteristics of the terrain are of the important for the planning of industrial facilities, further geochemical composition is essential for the planning and agriculture development. For the tourism development, from the point of use for therapeutic purposes, balneological characteristics of the hot water are of the important.

The research results will be presented on geochemical maps, tables and charts, with special emphasis on Vranjska spa and its importance in the development of health tourism in the region.
\end{abstract}

Keywords: spatial planning, geochemistry, Vranje basin, mineral resources, spa

\section{INTRODUCTION}

In the phase of nuclear materials research [1,2] in the area of Vranjsko -tertiary basin, in the superficial of $112 \mathrm{~km}^{2}$, hydrogeochemical researches were applied. In the first 